\title{
MAPPING OF MUSLIMS' UNDERSTANDINGS ON GENDER ISSUES IN ISLAM AT SIX UNIVERSITIES IN YOGYAKARTA, INDONESIA ${ }^{1}$
}

\author{
Alimatul Qibtiyah \\ Sunan Kalijaga State Islamic University (UIN) Yogyakarta, Indonesia \\ Email: alimatulqibty@gmail.com
}

\begin{abstract}
There is considerable disagreement among Muslims in how Islam says about many gender issues. One factor that influences the ways in which people understand gender issues in Islam and deal with the associated controversy is the approach they take when reading and interpreting Islamic texts. Some research has been done on the variety of thoughts on Islamic studies, but mapping thoughts comprehensively on gender issues not yet explored. This paper maps the Muslims' understanding of six contentious gender issues in Islam into three approaches: textualist/ conservative, semi-textualist/ moderate, and contextualist/progressive approaches. I document the diversity of thought among feminist and non-feminist Muslim intellectuals on gender issues (in the
\end{abstract}

${ }^{1}$ Thank you very much for DIKTI Scholarship for supporting this research. This research is part of my dissertation, therefore, I would like to express my appreciation to Professor Julia D Howell and Professor Mary Hawkins who have sharpened my analyses of the mapping on conceptualisation of gender issues by Muslim gender studies elites. I wish to thanks for all of my key persons and respondents in the Centre for Women Studies and Centre for Gender Studies at six Yogyakarta universities, UIN Sunan Kalijaga, UII, UMY, UGM, UNY and UPN "Veteran” Pembangunan Yogyakarta. Without your contributions, this work would never have been accomplished. My thanks also to all professors, staff and friends at the Centre for the Study of Contemporary Muslim Societies, University of Western Sydney for facilitating my realization that religion and feminism can work hand-in-hand when dealing with women's problems. 
light of their faith) using documentation and in-depth interview techniques. 25 respondents (male and female) from six universities in Yogyakarta were selected in this research. Textualist/conservative and contextualist/progressive scholars show the most strongly contrasting views on gender issues in Islam. Semi-textualist/ moderates present their views relatively flexibly: sometimes their views match those of the textualist/conservatives: sometimes they align closely with the contextualist/progressives. Based on their views and the arguments they present, semi-textualist/moderates' and contextualist/progressives' views seem close to the stance adopted by many Islamic Feminist.

Masih terdapat perbedaan pendapat antar umat Islam memahami isu gender. Salah satu faktor berpengaruh dalam pemahaman isu gender pada Islam adalah hal kontroversial dalam pendekatan pembacaan dan penafsiran teks agama. Beberapa penelitian telah mengkaji keragaman dalam pemikiran keislaman, namun pemetaan pemikiran secara komprehensif mengenai isu gender belum banyak. Tulisan ini memetakan pemahaman para feminis tentang enam isu gender dalam Islam di tiga kelompok (1) tekstual konservatif, (2) semi tektual - moderat, dan (3) kontekstual - progresif. Artikel ini mengambil lapangan di 6 universitas Yogyakarta dengan wawancara lebih dari 25 informan laki - laki dan perempuan baik. feminis dan non feminis. Kelompok tektualis dan kelompok kontekstual merupakan dua kelompok yang saling bertentangan dan kelompok semi tekstual lebihpada fleksibel. Terkadang pandangan ke tiga kelompok bergeser saling mendekat dan menjauh. Berdasarkan pandangan dan argumentasi ke tiga kelompok tersebut, semi tektual dan kontekstual menggambarkan kecondongan lebib banyak pada adopsi feminis muslim].

Keywords: Gender in Islam, Literalist, Moderate, scholars, Yogyakarta

\section{A. Introduction}

In the midst of the emerging democratic society and with the growing influence of Middle Eastern Islam on Indonesia, Indonesian gender activists are proposing new paradigms and concepts pertinent to gender equality in Islam. They criticize the gender ideology being promoted by the New Order as well as by Islamist or Salafi revivalist groups. In addition, they argue that Islam could be a source of gender equality if Muslims interpret religious texts properly and contextually. 
Should they fail in this respect, Muslims' limited understanding of the Islamic texts could create further gender problems for Indonesia. Gender activists believe that Islam brings mercy for all creatures (Quran, 21:107) and "frees human beings from oppression and discrimination due to sex, race, and ethnicity" (Quran, 49:13). ${ }^{2}$ They stress that egalitarian interpretations which emphasize justice for all and equality between men and women (Quran, 33:35), will improve women's position in society. Although gender activists have the same goals in improving women's life, in reality they have different approaches toward understanding gender issues.

Debate among Muslims over understanding gender issues in Islam first arose in recent times when the relation between text and history was discussed. Generally scholars contrast two principle approaches to, or methods of understanding, religious texts: 'textual' and 'contextual'.' According to Abdullah Saeed, there are three approaches may be identified in relation to the interpretation of ethico-legal content of the Qur'an in the contemporary era: Textualist, Semi-textualist and Contextualist ${ }^{4}$. Saeed gives example on general topics, which is not focusing on gender issues in Islam.

Amelia Fauzia and Jajat Burhanuddin on their research classify Muslims thought on gender into three categories: conservative, moderate and liberal ${ }^{5}$. Their classification is based upon the ways in which Muslims interpret religious texts and their attitudes towards Western feminists. According to Fauzia and Burhanuddin, the conservative approach interprets religious texts literally. Conversely, people on the liberal side understand them contextually and apply a hermeneutic approach. Between the two is moderate thought which interprets the religious texts

2 Pieternella van Doorn-Harder, Women Shaping Islam: Reading the Qur'an in Indonesia (Urbana: University of Illinois Press, 2006), p. 7.

3 Taufik Adnan Amal and Samsu Rizal Panggabean, "A Contextual Approach to the Qur'an", in Approaches to the Qur'an in Contemporary Indonesia, ed. by Abdullah Saeed (London: Oxford University Press, 2005), pp. 107-34.

4 Abdullah Saeed, Interpreting the Qur'an: Towards a Contemporary Approach (London; New York: Taylor \& Francis, 2996), p. 3.

${ }^{5}$ Jajat Burhanudin and Oman Fathurahman (eds.), Tentang Perempuan Islam: Wacana dan Gerakan (Jakarta: Gramedia Pustaka Utama \& Pusat Pengkajian Islam dan Masyarakat, 2004), pp. 187-207. 
inconsistently, sometimes using textual/literal approach, and at other times using contextual approach. On textual approach they explain the gender roles in the family, how the wife must always serves her husband and accepts other wives come to their family. On moderate view they give example on polygamy, leadership and gender roles in the family. On liberal interpretation, Fauzia and Burhanuddin explain about gender roles in public and women creation.

Woodward ${ }^{6}$ argues that the current phenomena of Indonesian Islamic thought can be classified into five variants: (1) indigenised Islam, (using Geertz's term, abangan) in which a group formally identifies as Muslim but in practice tends to accept syncretise religion with local cultural systems; (2) the traditional Sunni Islam of Nabdlatul Ulama $(\mathrm{NU}){ }^{7}$ which highlights the classical legal, theological and mystical texts. The adherents of the are usually from pesantren (Islamic Boarding houses) and rural areas, and accept a local culture as long as Islamic values are not contested; (3) the Islamic modernism of Muhammadiyah, ${ }^{8}$ which concentrates on modern education and social agendas and rejects mysticism. Its adherents are mostly from the urban areas; (4) Islamist groups, which promote a highly politicised and anti-Western interpretation of Islam, and whose discourse is centred on jibad and Shariah law. They are most commonly found on university campuses and in large urban areas; and (5) Neomodernism, which tries to discover an Islamic foundation for many types of modernity including tolerance, democracy, gender equity and

${ }^{6}$ Mark R. Woodward, "Indonesia, Islam, and the Prospect for Democracy", SAIS Review, vol. 21, no. 2 (2001), pp. 29-37.

7 Nahdlatul Ulama (NU) was established in Surabaya in 1926 to strengthen traditional Islam. This organisation is seen as traditionalist due to its being supported by people in the rural areas. Pesantren in this classification refers to NU-affiliated pesantren. It has a membership of approximately 40 million. Abdullah Saeed, "Introduction: the Qur'an, Interpretation and the Indonesian Context", in Approaches to the Qur'an in Contemporary Indonesia, ed. by Abdullah Saeed (London: Oxford University Press, 2005), pp. 107-34.

8 Muhammadiyah is an Indonesian Islamic organisation founded in 1912 by Ahmad Dahlan in the city of Yogyakarta, as a reformist socio-religious movement, advocating ijtihad (creative interpretation of the Qur'an and Hadith). It is one of the two largest Islamic organisations in Indonesia with 30 million members. Although Muhammadiyah leaders and members are often actively involved in shaping the politics in Indonesia, Muhammadiyah is not a political party. 
pluralism. The neo-modernists are concerned more with Muslim values and ethics than with law. They synthesize of traditionalist and modernist Islamic thought in Indonesia. ${ }^{9}$

Based on the range of topic discussed by Saeed, Fauzia-Burhanudin and Woodward, I argue that mapping Muslim understanding on gender issues based on the three categories has not been explored intensively. Therefore, in this paper I explore six selected contentious gender issues in Islam using three approaches as proposed by Saeed and FauziaBurhanuddin. Woodward's variant helps me to find out sources from the group or scholars that I can refer to for dynamic thoughts of gender issues in Islam. It is important to note here that organisation affiliations and the orientation of people's thought do not always coincide. For example, not all people from NU or Muhammadiyah organisation are of moderate orientation.

Drawing on these three schemas, I map Muslim gender activist's understanding on gender issues into three approaches, namely Textualist/ conservative, Semi-Textualist/moderate, and Contextualist/progressive. Much like Fauzia-Burhanuddin catagory, but, I relate those categories to the approches proposed by Saeed, and variants of Indonesian Islamic thought identified by Woodward. Thus, my Textualist/conservative category covers what Saeed argue as textualist, Fauzia-Burhanuddin refer to as 'conservative' ideas and what Woodward refers to as the fourth variant, "Islamist groups". I use the term 'Textualist-conservative' because usually the mainstream thought pertaining to, or interpretation of, the religious texts by Islamists and conservative orientation is textual. My 'Semi-textualis/moderate' category combines Saeed's idea on Semi-Tektualist, Woodward's 'indigenous' Islam, and his 'NU' and 'Muhammadiyah' variants and Fauzia-Burhanuddin's term 'moderate'. My last category, the 'contextualist/progressive', is similar to the 'liberal' orientation proposed by contextualist by Saeed, Fauzia-Burhanuddin, and to Woodward's 'neo-modernist' category. I use this term because the neo-modernist orientation usually employs a contextual approach and has a liberal contextualist-progressive orientation.

Exploring and mapping the Muslim gender activists' understanding

9 Greg Barton, "Neo-Modernism: A Vital Synthesis of Traditionalist and Modernist Islamic Thought in Indonesia", Studia Islamika, vol. 2, no. 3 (1995), pp. 1-76. 
on gender issues in Islam is important to study. The research finding contributes to understand the normative work that has been done by Muslim scholars relating to gender issues-what are the religious texts they refer when discussing gender issues in Islam. It can also be used to assert that Muslim gender activists' understanding on gender issues is not monolithic. The most important contribution of this research is proposing a tool to measure the level of Muslim's understanding on gender issues in Islam. By understanding the level then it helps the mainstreaming gender equality values in the society.

This research shows how the Muslim men and women of six gender study centers in Yogyakarta universities understand six contentious gender issues in Islam. It is designed to fill a gap in research on Indonesian gender activists. Until now, scholarship on feminism and Islam has not investigated gender activists in Indonesian universities. Thus although the findings on the gender study centers in Yogyakarta that are the subject of this study cannot be generalized beyond those centers, they do reveal the complexion of this one arena of the under-studied field of Indonesian feminism and gender activism among Muslims.

This research was conducted in Yogyakarta, a special province located in the central area of Java. I chose Yogyakarta for several reasons: It is known primarily as an educational and cultural city. There are 123 PSWs/PSGs across Indonesia, 15 of them located in Yogyakarta. In 1928, first Indonesia National Women Congress was conducted in Yogyakarta. Aisyiyah, active member of that Women Congress, the longest-serve Muslim women's organisation was established in this city and, until today, its national board is in Yogyakarta. Many women's NGOs were originally established there such as: LSPPA, Riflea Anisa, YASANTI, Tjut Nyak Dien, and Dian Desa.

This is a qualitative research and data was collected from in-depth interview and documentation. I selected 25 respondents based on sexes, university affiliations, ages and ethnicity from five Pusat Studi Wanita/ PSWs (Centres for Women's Studies) and one Pusat Studi Gender/PSG (Centre for Gender Studies) at six universities in Yogyakarta. Three were Islamic universities: PSW UIN (State Islamic University) Sunan Kalijaga Yogyakarta, PSG UII (University of Islam Indonesia) and PSW UMY (University of Muhammadiyah Yogyakarta) and from three 
public universities: PSW UGM (Gadjah Mada University), PSW UNY (State University of Yogyakarta) and PSW UPN "Veteran" (University of National Development "Veteran"). The characteristics of the respondents were as follow: (a) Gender activists and scholars concerned with gender or/and women issues associated with universities; (b) Members of the PSWs/PSG in Yogyakarta (everyone connected with a PSW/ PSG is by definition gender activist, including former staff, staff, and associate members/volunteers); (c) Muslim; and (d) Males and females. Respondents' name is reported as anonym (not the real name).

Data was analysed using Miles and Huberman interactive model: data condensation, data display, drawing and verifying conclusion ${ }^{10}$. There are six selected gender issues in this research, namely: 1) Equal status men and women; 2) Equality of gender roles in the home and workplace; 3) Equal power to make decisions in family life; 4) Equal rights to inheritance; 5) Equal value as a witness; 6) Symbolic equality of women in the creation story. I report each gender issue in accordance with Islamic texts from the Qur'an and Hadith: this is followed by the in-depth interview result that classified into three approaches: Textualist/ conservative, Semi-Textualist/moderate, and Contextualist/progressive.

\section{B. Mapping Muslims' Understandings of Gender Issues in Islam}

Before exploring Muslims' understanding of gender issues in Islam at six universities in Yogyakarta, I explain the nature of three approaches used in this research as previously mentioned. According to Saeed, Textualists argue that the meaning of the Qur'an is fixed and universal in its implementation. They follow the text strictly and adopt a literalistic approach to the text. In line with Saeed, Amin Abdullah ${ }^{11}$ and Anwar Syafi' ${ }^{12}$, highlight that the textualists believe text is accepted as if it has not been shaped by people throughout the course of history. Its meaning is seen as being wholly attributed in the historical time in

10 Matthew B. Miles, A. Michael Huberman, and Johnny Saldana (eds.), Qualitative Data Analysis (Los Angeles: SAGE, 2014), pp. 12-3.

${ }^{11}$ M. Amin Abdullah, Studi Agama: Normativitas atan Historisitas? (Yogyakarta: Pustaka Pelajar, 1996), pp. 3-18.

12 M. Zaki Mubarak, Genealogi Islam Radikal di Indonesia: Gerakan, Pemikiran, dan Prospek Demokrasi (Jakarta: LP3ES, 2008), p. xvii. 
which it was first received. Textualists claim that key religious teachings have not changed over time and that understanding of them may not be changed even slightly as societies change. From their perspectives, the supposed original meanings remain valid over all periods of time and in all places. They ignore the later religious scholarship of the classical schools. Interpreted this way, the meaning of any text or passage is not problematical. According to Fazlur Rahman, textualists evince 'a general failure to understand the underlying unity of the Qur'an'. ${ }^{13}$ They fail to recognise the difference between general principles and specific responses to concrete and particular historical occurrences. Traditionalists and Salafist mostly adopt this approach. ${ }^{14}$

The textualist-conservatives' interpretations of gender issues are based upon literal interpretations of passages relating to women's issues in the canonical religious texts, the Qur'an and Hadith. Because of their literalism in taking revelations received in an ancient patriarchal society at face value, the interpretations are usually misogynistic, positing women's roles, statuses, and rights as inferior to those of men. In general, textualist-conservatives are against the Pembaharuan (reform) philosophy, including its position on gender and feminism. They claim that gender and feminism are Western ideologies not suited to Islamic traditions. Furthermore, they argue that people who follow any ideology outside Islam are transgressing Islamic law and against God. ${ }^{15}$

The second approach according to Saeed is Semi-textualist. "Semi-textualists essentially follow the Textualists as far as linguistic emphasis and ignoring of the socio-historical context are concerned, but they package the ethico-legal content in a somewhat 'modern' idiom, often within as apologetic discourse". ${ }^{16}$ Modernists and neo-revivalist movement, such as Muslim Brotherhood (Egyp) usually adopt this approach. This orientation accepts feminist ideas as long as there is no conflict with what they see as basic Islamic values. They argue that not

13 Fazlur Rahman, Islam \& Modernity: Transformation of an Intellectual Tradition (Chicago: University of Chicago Press, 1982), p. 22.

14 Saeed, Interpreting the Qur'an, p. 3.

15 Burhanudin and Fathurahman (eds.), Tentang Perempuan Islam: Wacana dan Gerakan, p. 188.

16 Saeed, Interpreting the Qur'an, p. 3. 
all feminist ideas are from the West. Islam originally opposes gender inequality at its foundation; therefore, the feminist spirit is compatible with Islamic values. Everything is explained in the Qur'an and Hadith, including gender relationships. However, unlike the first category, those with Semi-textualist or moderate orientation do not always read and understand the religious texts literally. Sometimes they use contextual methods depending upon the need. ${ }^{17}$

Last approach according to Saeed is contextualist which emphasize the socio-historical context (political, social, historical, cultural, and economic contexts) when the Qur'an was revealed. Muslim thinkers today have a high freedom in determining what is changeable and unchangable in the area of ethico-legal content ${ }^{18}$. Scholars who adopt this approach seek recourse to the canonical texts (the Qur'an and Hadith); then they broaden the scope for the ijtihad (interpretation) of said texts by considering the influences of place and time on the original revelation of the holy words and examples and on the recording of the texts. Thus, they understand them as shaped by the socio-cultural and geographical conditions of different times and places. They also use a variety of disciplinary approaches, from history, philosophy, psychology, sociology and anthropology, to help reach an interpretation, and which are thought to produce better understandings of the meaning of the texts ${ }^{19}$. Significantly for this research, contextual approaches can deconstruct religious dogma that does not support gender equality and reconstruct it as support for gender equality. But, because such dogma has been internalised in the beliefs of Muslims for centuries, it is not easy for liberal groups to challenge gender views long established in a given society or to address the social problems that result from them.

One way to reinterpret the Islamic texts as implement by contextualists is using hermeneutical approach. It involves re-thinking or imaginatively re-experiencing what the author originally felt or thought. ${ }^{20}$ Giving attention on asbabul wurud is one of effort to understand the

17 Burhanudin and Fathurahman (eds.), Tentang Perempuan Islam, p. 149.

18 Saeed, Interpreting the Qur'an, p. 3.

19 Abdullah, Studi Agama, pp. 14-5.

${ }^{20}$ Josef Bleicher, Contemporary Hermeneutics: Hermeneutics as Method, Philosophy and Critique (London ; Boston: Routledge \& Kegan Paul, 1980), p. 1. 
substantial meaning which is usually conservative group do not believe on that ${ }^{21}$. Wadud, one of the best known feminist exponents of hermeneutics in Qur'anic exegesis argues that the hermeneutic approach can be applied to analyze women's issues. ${ }^{22}$ Through hermeneutics, Muslim feminists and neo-modernists tend to reread the texts, emphasising the notions of equality and justice in men's and women's roles in society, which are "complementary and egalitarian rather than hierarchical and unequal"23. Neo-Medernists, ijtihadist, contextualist-progressive Muslim, liberal Muslim scholars generally implement this approach. ${ }^{24}$ Nina Nurmila catagorizes this group as Muslim Feminists not Islamist Feminists. ${ }^{25}$ Islam Liberal's concept is developed by young intellectual activists from Muhammadiyah and Nahdatul Ulama. ${ }^{26}$

\section{Six Selected Gender Issues in Islam}

As mentioned earlier, after discussing the nature of approaches I will explore Muslim's understandings of six selected gender issues by classifying them into three approaches. Here I discuss each gender issue in accordance with Islamic texts from the Qur'an and Hadith and followed by different understandings from respondents collected from in-depth interview.

21 David Kloos and Ward Berenschot, "Citizenship and Islam in Malaysia and Indonesia", in Citizenship and Democratization in Southeast Asia, ed. by Ward Berenschot, H.G.C. Schulte Nordholt, and Laurens Bakker (Leiden: Brill, 2016), p. 196.

22 Amina Wadud, Qur'an and Woman: Rereading the Sacred Text from a Woman's Perspective, 2nd ed. edition edition (New York: Oxford University Press, 1999), p. 3.

23 Asma Afsaruddin, Hermeneutics \& Honor - Negotiating Female "Public" Space in Islamic/ Ate Societies (Cambridge: Harvard University Press, 2000), p. 23.

24 Saeed, Interpreting the Qur'an, p. 3.

25 Nina Nurmila, "The Influence of Global Muslim Feminism on Indonesian Muslim Feminist Discourse”, Al-Jami'ab: Journal of Islamic Studies, vol. 49, no. 1 (2011), p. 37.

26 Kamaruzzaman Bustamam-Ahmad, "Contemporary Islamic Thought in Indonesian and Malay World: Islam Liberal, Islam Hadhari, and Islam Progresif", Journal of Indonesian Islam, vol. 5, no. 1 (2011), pp. 91-129. 


\section{Equal Status of Women}

In the Islamic context, there are several religious texts with implications for assigning status to men and women. Muslims commonly cite An-Nisa, 34: "Men are the protectors and maintainers (Qowwam) of women, because Allah has made one of them to excel the other and because they spend (to support them) from their means" ${ }^{27}$, Al Qur'an Al-Ahzab, 33: mentions "And stay in your houses, and do not display yourselves like that of the times of ignorance". ${ }^{28}$ They also cite AlBaqara, 282:

And get two witnesses out of your own men. And if there are not two men (available), then a man and two women, such as you agree for witnesses, so that if one of them (the two women) errs, the other can remind her. And the witnesses should not refuse when they are called (for evidence) ${ }^{29}$

Muslim gender activists have different interpretation of women's status based on these texts. In order to understand how they explain their views on women's status with respect to men, I asked the respondents whether she/he tended to see women's status as 'equal complementary' or 'equal partnership' with men. In the Muslim community, there is assumption that men should share equal status with women in all aspects of life (equal partnership). In contrast, there is another belief that men should be accorded a higher status than women. Again, some believe that although men should occupy a higher status than women, in effect they complement each other equally. The term 'equal complementary' (setara tapi berbeda/saling melengkapi) implies the notion that men and women are not only equal but also different. But, this difference does not mean that one is higher or better than the other, a concept that tends to support the maintenance of traditional gender roles. In contrast, 'equal partnership' (setara) suggests that men and women should have equal

${ }^{27}$ Mohsin Khan (tran.), “An-Nisaa: 34”, 4. An-Nisaa, 176 verses, The Women, Medinan, https:/ / www.searchtruth.com/chapter_display.php?chapter=4\&translator=5\&show_ arabic $=1$, accessed 11 Feb 2017.

${ }^{28}$ Mohsin Khan (tran.), "Al-Ahzaab: 33", 33. Al-Ahzaab, 73 verses, The Clans, Medinan, https://www.searchtruth.com/chapter_display.php?chapter=33\&translator= 5\&show_arabic=1, accessed $11 \mathrm{Feb} 2017$.

${ }^{29}$ Mohsin Khan (tran.), “Al-Baqara: 282", 2. Al-Baqara, 286 verses, The Com, Medinan, https:/ / www.searchtruth.com/chapter_display.php?chapter=4\&translator=5\&show_ arabic $=1$, accessed 11 Feb 2017. 
access to resources, participate in equal opportunities to join in public and private activities, have equal access to power opportunities, to making decisions, and get equal benefit from the decisions made. According to this orientation, whoever is in charge of certain activity or a certain position should not depend upon one's sex (male or female) but on the person's abilities. This is also in accordance with the sameness, difference debate or the minimiser, maximiser theory discussed in the introduction. Whereas the sameness or maximiser theory argues that women should be seen through a prism which emphasises their similarities to men, the difference or minimiser theory holds that women are fundamentally different from men. ${ }^{30}$

In general, almost all of the respondents declared men and women's status equal in the eyes of Allah; but, there were a variety of responses when discussing different gender issues such as gender roles in the public and domestic spheres, equal rights to inheritance, and equal opportunity to be able to lead in prayer. Some contextualist/progressive respondents tended to see men and women as equal partnership whereas many semi-textualist/moderate respondents tended to see them as equal complementary. Strongly textualist/concervative respondents believed that men occupy a higher status than women.

Laila, a textualist/conservative female respondent from a public university, observed that men's and women's different statuses depend upon their kodrat (God-given nature). Men seem to have higher status than women because many of the instructions in the Qur'an are addressed to men not to women. "I feel that in the Qur'an Allah's commands tend to men instead of women, for example, command for Friday prayer is compulsory for men". ${ }^{31}$

One example, semi-textualist/moderate respondent, Maman, a male respondent from an Islamic university, argued that male and female relationships are not sub-ordinate but complementary, and, the different gender roles between men and women are not hierarchical but

${ }^{30}$ Carol Lee Bacchi, Same Difference: Feminism and Sexual Difference (Sydney: Allen \& Unwin, 1990).

31 Laila, interview (3 Jun 2010). 
functional. ${ }^{32}$ As asserted by $\mathrm{Umar}^{33}$ that the different kodrat (God-given nature), is part of the uniqueness and strength of each sex. Therefore, one cannot say that one is less valued or makes a lesser contribution than the other, or vice versa.

Contextualist/progressive respondents such as Wira ${ }^{34}$ argued that men and women can claim equal partnership both theologically and philosophically and their existence as azwaj (couples), men cannot live without women, and conversely, women cannot live without men. Gizela similarly observed:

I am as a person who has a direct access to the religious text and I argue that there is no single text legitimizing men and women should be treated differently. The only consideration is their piety (ketaqwaan) to God and only God knows and can measure a person's piety. ${ }^{35}$

Contextualist/progressive respondents' idea in line with contextualist/progressive scholars' argument ${ }^{36}$ that men and women are meant to enjoy an equal partnership. Not only should they be equal in the eyes of God but they should also have equal gender roles in the family, society and in ritual activities. Contextualist/progressive scholars, aware of the fact that men and women are biologically different, claim that women have more reproductive tasks than men. But, this does not imply that women's status is higher than men's or vice versa.

Based on above explanation it can concluded that textualist/ conservative people argue that men enjoy a higher status than women because many Islamic texts tell about men's privileges such as leadership, witness and creation. Whereas semi-textualist/moderate scholar assert that men and women are equal complementary. Last position, contextualist-progressive people note that men and women have different kodrat and roles but these differential matters are to be used to undermine

32 Maman, interview (5 May 2010).

33 Fatima Umar Naseef, Menggugat Sejarah Perempuan: Mewujudkan Idealisme Gender Sesuai Tuntunan Islam, trans. by Burhan Wirasubrata and Kundan D. Nuryakien (Jakarta: Cendikia Centra Muslim, 2001), pp. 77-9.

34 Wira, interview (8 May 2010).

35 Gizela, interview (25 May 2010).

36 Siti Musda Mulia, Muslimah Reformis: Perempuan Pembaru Keagamaan (Bandung: Mizan, 2005), p. 7. 
others. Men and women are equal partnership. Allah creates them from the same essence therefore they have equal status and equal roles in domestic and public lives.

\section{Equality of Gender Roles in The Home and Workplace}

In Islam, the equality of men's and women's roles at home and workplace relates to the notion of kodrat. More broadly speaking, it is a power, an ability or capacity that allows someone to do a particular thing: it is determined by God, and humankind cannot change or reject. One Qur'anic verse to which Muslim scholars refer when commenting on women's God-given nature is $\mathrm{Al}$ Ahzab, 33:

And stay quietly in your houses, and make not a dazzling display, like that of the former Times of Ignorance; and establish regular Prayer, and give regular Charity; and obey Allah and His Messenger. And Allah only wishes to remove all abomination from you, ye members of the Family, and to make you pure and spotless. ${ }^{37}$

Related to the issue of equal gender roles in public and domestic life was the issue of who should be the main breadwinner (earning nafkah). This is one of the particularly contentious gender issues in Islam. Even among Muslim gender activists and scholars whose responses tended towards the contextualist/progressive, a variety of understandings were revealed in the in-depth interviews. The different views about who is the main breadwinner (pencari nafkab) among contextualist/progressive people hinged upon the fact that women are biologically different from men. Reproductive tasks such as pregnancy and breast feeding cannot be undertaken by men. Thus, one position taken was that women's reproductive tasks need to be given special attention. Therefore, she should not be burdened with responsibility to be main breadwinner. On the other hand, some respondents pointed out, that reproductive tasks are negotiable and can be managed. Thus, by involving men in reproductive tasks and domestic tasks, women will be doubly burdened.

Although all of the respondents were employed at universities as lecturers, researchers or other staff, they had different ideas about the concept of who is the main breadwinner. Some argued that nafkah (food expenses, accommodation, security and protection to the family) is the

37 Mohsin Khan (tran.), "Al-Ahzaab, 33". 
responsibility of both men and women, others that nafkab is the man's responsibility.

Some textualist/conservative respondents argued that the main responsibility of the husband/father was to provide nafkab because it is part of his duty. This argument in lines with textualist/conservative scholar who argue that God imbued them with different kodrat and for this reason they perform different roles. ${ }^{38}$ If a wife or a mother earns money, then the money is only considered as additional or complementary nafkah for the family. A woman's main duty is not to earn money but to take care of the children and doing the domestic tasks. For example, Joko ${ }^{39}$, a male respondent from an Islamic university, reported that nafkab is the husband's obligation and that if the wife earns money, it is part of her shodaqob (charity) to the family. Hary a male respondent from a public university, asserted that the husband has to fulfil the needs of his wife and children ${ }^{40}$. Laila, a female respondent from a public university, said that nafkab is a man's obligation because physically a man is stronger to work and to deal with problems in the work place than a woman and he also has more freedom in the community. ${ }^{41}$

Semi-textualist/moderate respondents argued that nafkah is the man's responsibility because women have difficult and complex reproductive tasks. If a woman has the same duty as a man to earn money, it will be a double burden for her. According to views categorised as 'semitextualist/moderate', women are naturally responsible for the domestic sphere, whereas men are naturally active in the public domain. However, under certain conditions, they deem it acceptable for women to contribute to family income, their contribution is considered additional family income. This idea has been implemented widely in Indonesian culture through the ideology of 'state ibuism' initiated during the New Order Era. ${ }^{42}$

38 Buletin Al-Ilmu, "Kedudukan Wanita dalam Islâm”, Akhwat.web.id, http:// akhwat.web.id/muslimah-salafiyah/membantah-feminis/kedudukan-wanita-dalamislam/, accessed 12 Apr 2018.

39 Joko, interview (24 May 2010).

40 Hary, interview (2 June 2010).

41 Laila, interview (3 June 2010).

42 Julia I. Suryakusuma, Sex, Power, and Nation: An Anthology of Writings, 19792003 (Jakarta: Metafor, 2004). 
Semi-textualist-moderates also argue that the main responsibilities for women are motherhood and child care.

For example, Sita, a female respondent from an Islamic university claimed that nafkah is a man's obligation because:

In the Qur'an it (nafkah) is the husband's responsibility because in Al Baqoroh. Islam recognises women's reproductive tasks. the fundamental values which in nafkah is designed to support them. If a wife earns money, it is for herself normatively. In society the problem is not about nafkah but the logical consequences behind that. People often say that nafkah is the husband's duty then as a consequence, he must be obeyed and have absolute authority, this is the logic of capitalism. When the Qur'an states nafkah, it is as a reminder that the reproductive tasks for a woman are very hard, so she does not need to earn nafkah, actually, the Qur'an does not state that it is an obligation (wajib) or not, it emphasises that earning nafkah for the husband is equal to reproductive tasks for the wife. It does not mean that just because he earns nafkah he automatically becomes head of the family. For me it is not the case. ${ }^{43}$

Some respondents, who expressed a contextualist/progressive view, argued that both the husband and wife have the same responsibility to be breadwinners; but, the responsibility will be flexible given that the wife's reproductive tasks cannot be undertaken by her husband. This means that if a wife is engaged in reproductive tasks such as pregnancy or breast feeding, then the main responsibility for nafkah must be borne by husband. Feminist scholar ${ }^{44}$ Subhan argues that although men and women have different kodrat, they have equal roles in public and domestic life. Men and women's creation is from the same essence; therefore, they should be encouraged to become actively involved in both the domestic and public spheres. ${ }^{45}$ Permata and Rama argued that the involvement of both partners as breadwinners is not rigid but should be flexible:

I think women's kodrat is not a barrier for a woman to get involved in contributing to the family income as long as there is cooperation from her husband to be involved in the consequences of reproduction and other domestic tasks. For example, when the wife breast feeds at night

43 Sita, interview (3 June 2010).

44 Zaitunah Subhan, Menggagas Fiqh Pemberdayaan Perempuan (Jakarta: el-Kahfi, 2008), p. 281.

45 Ibid. 
the husband helps her to prepare food if she needs some. ${ }^{46}$

In my opinion, ideally both partners have the same responsibility for earning nafkah, because for me women's kodrat such as pregnancy is negotiable and socially constructed, although in society many people believe that it is the man's responsibility and therefore, he has more chance and authority to contribute financially to the family. For me, this is not the ideal condition. ${ }^{47}$

According to Ita, a female respondent from a public university, the family will get more benefit if both husband and wife contribute to the family income. In this way, the economic burden will be alleviated particularly as in the current situation the prices of basic necessities have increased significantly. Therefore, if both parties have paid jobs the family will have more healthy food. ${ }^{48}$ Another female respondent Tria. ${ }^{49}$ argued that a dual breadwinner family will enjoy advantages for both the husband and the wife. For the husband, in the competitive era of today, sometimes it will be difficult to find a good job; so, if the wife shares the responsibility to fulfil the family's needs, the husband will be relieved of this burden and stress. Perhaps more importantly from a gender perspective, for the wife, it erases the notion that the economic contribution of a woman to the family is not simply an additional or complementary income. She can be considered a main breadwinner in her own right, creating a balance in the relationship and assuming an equal share of power in the family.

Based on the above exploration it can be concluded that textualist/ conservative people argue that women's kodrat is best fulfilled by being at home, doing domestic work and raising children, whereas men's kodrat is properly expressed in public and by earning money. Therefore, it is not appropriate for a husband to do domestic tasks such as washing, ironing, cooking, cleaning and child care. Whereas Semi-textualist/moderate scholars assert that Islamic teaching prioritises women's domestic roles and requires women to have a major role in bringing up children; a woman

\footnotetext{
46 Permata, interview (22 June 2010).

47 Rama, interview (11 June 2010).

48 Ita, interview (27 May 2010).

49 Tria, interview (May 2010).
} 
can work outside of the home but it is not necessary to develop her career because her main responsibility should be in the domestic sphere. Women earn money for additional income. Contextualist/progressive people argue that childbirth and breastfeeding are women's kodrat (natural or inborn qualities), whereas raising a child and doing housework are socially constructed. Therefore, gender roles and domestic tasks can be done by either men or women. Both men and women should be encouraged to take their place in the public and domestic spheres.

\section{Equal Power to Make Decisions in Family Life}

Decision making in the family hinges upon gender roles in the public and domestic spheres. People tend to link the issue with the concept of leadership in the family described in the Qur'an in An-Nisa, 34: "Men are the protectors and maintainers (Qomwam) of women, because Allah has made one of them excel more than the other and because they spend (to support them) from their means". ${ }^{50}$ The concept of kepala keluarga is related to gender issues, i.e., equal right to make decisions regarding the family.

Mimi, a textualist/conservative female respondent from an Islamic university argued that the head of a family should be a man:

For me, a man as the head of the family is still relevant because that is the rule, one of the jobs of the head of the family is making decisions for the family, if he could not make decisions for psychological reasons such as having mental disorder, then the job can be transferred to his wife, the husband is the leader and the wife is the manager. ${ }^{51}$

Textualist/conservatives believe that all family decision making should be done by the head of the family, i.e., the father and husband. Scholars from the textualist/conservative group argue that a man is the head of the family because he is the breadwinner. Furthermore, people in this group say that the man is head of the family because men are both physically and psychologically more capable than woman. A woman is responsible for taking care of her husband's house and the household. ${ }^{52}$

50 Mohsin Khan (tran.), “An-Nisaa, 34”.

51 Mimi, interview (16 June 2010).

52 Naseef, Menggugat Sejarah Perempuan: Mewujudkan Idealisme Gender Sesuai Tuntunan Islam, pp. 227-9. 
Their arguments are based upon the following Hadith:

All of you are the leaders and have to be responsible to all followers. A man is a leader for his family and a woman is a leader and responsible for her husband's house and his offspring; so all of you are leaders and responsible for your followers. ${ }^{53}$

Some semi/textualist-moderate respondents' idea match with the government system, the 1974 marriage law, ${ }^{54}$ which states that father/ husband is head of the family, and a mother/wife is head of household. Therefore, it is better men make decisions regarding issues of public life and women make decisions in the areas of domestic life. ${ }^{55}$ However, people in this group insist that to be head of a family is a responsibility, not a privilege, for men. Therefore, a man cannot undermine his wife because of his position as head of the family. Head of family is only a formal administration and not hierarchical rather just functional. ${ }^{56}$ Ana, a female respondent from a public university stated:

It doesn't matter that a man is the head of the family, because it is appropriate according to the state, I just want to follow the state rule, but if there is no man then a woman can be the head of family, the head of the family is functional not hierarchical. ${ }^{57}$

Some contextualist/progressive respondents asserted that the family does not need a head because in reality many families are managed by all family members. Both men and women can be heads of families, depending upon their capabilities and the commitment among family members. Contextualist/progressive people's views are not only constructed around v erses in the Qur'an but also based on social reality, taking into account the Indonesian Child Protection Law no 23 year 2002 article $10 .{ }^{58}$ In addition, contextualist/progressive scholars argue

53 Ibid., p. 244.

54 Republic Indonesia, Marriage Law of 1974, Article 31:3 Suami adalab Kepala Keluarga dan isteri ibu rumah tangga [husband is the head of the family and the wife the housewife] (1974).

55 Naseef, Menggugat Sejarah Perempuan: Mewujudkan Idealisme Gender Sesuai Tuntunan Islam, p. 229.

56 Subhan, Menggagas Fiqh Pemberdayaan Perempuan, pp. 271-81.

57 Ana, interview (1 June 2010).

58 Republic Indonesia, Indonesian Child Protection Law no. 23. 2002, Article 10. 
that the head of the family may not necessarily be a man: it could be a woman, as far as she has the capability to lead. ${ }^{59}$ Musdah, criticising the term "kepala keluarga" (head of the family) in the Marriage Law 1974, claims that in society the term kepala (head) is often misused and given authoritarian implications. ${ }^{60}$ This misunderstanding leads many lesser educated people to interpret the law inappropriately; for example, the wife has to do all of the domestic tasks and serve all of her husband's needs. In addition, Musdah proposes amending the Marriage Law by removing the term kepala keluarga, because in reality, 1 out of 9 heads of families in Indonesia is female. Therefore, the Law is out of date. Wira, a male respondent from an Islamic university, stated:

The prophet Muhammad said that if you are in a group or travelling choose a leader. In my understanding, the head of family, can be someone who can give guidance, and for me it could be a man or a woman, for example, in prayer the first requirement is Aklamuhulfi ilmissolah, who has more knowledge in prayer. ${ }^{61}$

According to Gizela, a female respondent from an Islamic university, the concept of head of family itself needs to be reconstructed:

What does it mean being the head of the family? if it means someone who has a role as a decision maker, then it is not necessarily single but can be collective. In an Indonesian context, there are many single parents, therefore it is not relevant if the head of the family is a man. ${ }^{62}$

In summary, textualists/conservative argue that only the husband/ father has the right to make decisions in the family, because he is the head of the family. Whereas, semi-textualist/moderate people say that it is a better for the wife/mother to make decisions in the realm of domestic tasks and for the husband/father in the public domain. That man is the head of family and a woman is the head of the household is only a matter of functional positioning. It is not a hierarchical positioning. Contextualist/progressive people note that every family member has equal right to make decision in the family depending on their capability

59 Abdullah Faishal, "Konsep Qawwam di Dalam Al Qur'an”, in Relasi Jender dalam Islam, ed. by Erwati Aziz (Kartasura: PSW STAIN Surakarta Press, 2002).

60 Mulia, Muslimah Reformis, p. 271.

61 Wira, interview (8 May 2010).

62 Gizela, interview (25 May 2010). 
and capacity. A man or woman can be a leader of a family depending on their ability to lead. In the Indonesian context, notion of head of family (kepala keluarga) is no longer relevant.

\section{Equal Rights to Inheritance}

Before the time of the Holy Prophet Muhammad, women and children in Arab tribes could not claim inheritance; in fact, they were even part of inheritance itself. Heirs were only adult men who carried weapons and protected their tribes. ${ }^{63}$ Therefore, when Islam changed this tradition by giving women half the portion allocated to men, it seemed quite radical. ${ }^{64}$ Discussion of inheritance in Islam generally refers to the Qur'anic passages An-Nisa, 7 and 11, which state that both sons and daughters have rights to inheritance, although daughters should have a half portion only. ${ }^{65}$ Almost all of the respondents argued that the important value of inheritance involves how to uphold adl (justice). But, respondents had different views of understanding justice.

Example of textualist/conservative respondent who agreed that two portions for male heirs and one for female heirs were presented by Maman, a male respondent from an Islamic university. He explained that $2: 1$ portion is equal because if it is combined in the family, the husband gets two portions from his family and the wife gets one portion from her family: then the result is 3 portions. So, two portions for male heirs and one portion for female heirs is equal. ${ }^{66}$ This difference in treatment between men and women is usually explained by reference to the Qur'an and relates to the concept of nafkeah, i.e., that a wife is entitled to maintenance from her husband in terms of shelter, clothing, food and medical care. ${ }^{67}$ Some textualist-conservatives argue that this differential

63 Mohamad Guntur Romli, Muslim Feminis: Polemik Kemunduran dan Kebangkitan Islam (Jakarta: Freedom Institute, 2010), p. 205.

64 Subhan, Menggagas Fiqh Pemberdayaan Perempuan, pp. 259-62.

65 Mohsin Khan (tran.), "An-Nisaa: 7-11", 4. An-Nisaa, 176 verses, The Women, Medinan, https://www.searchtruth.com/chapter_display. php?chapter=4\&translator=5\&show_arabic=1, accessed 11 Feb 2017.

66 Maman, interview (5 May 2010).

67 Tim Lajnah Pentashihan Departemen Agama (ed.), Tafsir Al-Quran al Karim, vol. 2 (Kudus: Menara Kudus, 1996); Islam, Land and Property Research Series, vol. Paper 5: Muslim Women and Property (Nairobi: UN-HABITAT, 2005). 
treatment (2:1) is based upon the reckoning that women lack rationality and, that if they receive an inheritance, they may squander it on jewellery, dresses and other frivolities. ${ }^{68}$

Two examples of respondents who adopted a semi-textualist/ moderate position were Darma and Permata. The former argued that although the religious text states two portion for men and a single portion for women, in reality it can be interpreted in different ways based on certain circumstance in the family.

In my understanding, theologically Allah and the Prophet have reason that might be Muslim couldn't understand why women got a half inheritance to men. I try to understand what Allah thinks about inheritance. For me ... we could still implement 2:1 but we have to raise an awareness to share property to the one who needs most. ${ }^{69}$

Permata, a female respondent from an Islamic university, argued that the Islamic system of philanthropy placed a good value on inheritance. Unfortunately, this particular Islamic system is not implemented well in Indonesia.

Long time ago in the Prophet Muhammad era, if there was a widow, her brother or her uncle will fulfil her basic need; therefore, although women got a single portion it was not a problem, because there is somebody helping her to fulfil her basic needs... but this system does not exist anymore. As a result, it seems that Islamic law on inheritance 2:1 is not fair ... I will tell my case in my family. My oldest brother yelled at all heirs to ask his portion double compared to female heirs. But then I asked him to be responsible in nafkah to my older sister who was a widow until she got married again. My oldest brother did not agree with this idea. Then, the inheritance was divided equally between men and women in my family based on consensus among family members. ${ }^{70}$

Meanwhile, the semi-textualist-moderates agree with the textualistconservatives regarding inheritance; but, the latter encourage other charitable acts such as giving presents to or making a will (bibah) in favour of a woman, making her portion equal to that of a man. In the Indonesian context, this idea is similar to the Compilation of Islamic

68 Subhan, Menggagas Fiqh Pemberdayaan Perempuan, p. 257.

69 Darma, interview (9 May 2010).

70 Permata, interview (22 Jun 2010). 
Law (Kompilasi Hukum Islam/KHI) No. 1, 1991, Article 176, which states that inheritance should be divided based on gender, i.e., a daughter gets a half of that of her brother. Article 183 states that the family could sign an agreement for dividing the inheritance after all of the heirs are aware of their share. ${ }^{71}$ But, Indonesian communities that enjoy an egalitarian culture, may interpret this law differently from the majority of textualistconservatives. The former will decide that all men and women should share an equal right in inheritance as long as all inheriting members agree.

Some contextualist/progressive respondents argued that the different distributions of inheritance between men and women in the contemporary Indonesian context do not portray the justice value of Islam. In addition they argued that the important thing was adl (justice), not the portion itself. Most of them took a contextualist/progressive approach i.e., that men and women should inherit equally or that an inheritance should be divided based on need, regardless of gender. The following views expressed by Tria, Aisyah and Abdullah respectively.

Tria explained that although the Qur'an states two portions for men and one for women, this cannot be implemented in the current situation.

There are many cases in the family that a man is richer than his sister ... if a woman receives a half portion compare his brother, it will cause her to become poorer and vulnerable. I think it is not fair, because he is a man he gets double compared to his sister. For me, in Islam the basic value is justice and care for the needy. I imagine that the inheritance text was revealed to respond to the context at that time when women were part of the property, therefore they did not inherit property; from their parents even they are part of inheritance itself. ${ }^{72}$

Aisyah argued in favour of a double portion for men 'at that time' because there was a reason for it. Today there is no reason to divide an inheritance differently between men and women. Because both men and women have the same opportunities the inheritance should be divided equally. ${ }^{73}$ Abdullah's response was different. He argued that two portions for men and one for women was not fair because in the current situation

\footnotetext{
71 Republic Indonesia, Instruksi President: Kompilasi Hukum Islam (1991).

72 Tria, interview (May 2010).

73 Aisyah, interview (23 June 2010).
} 
both men and women are responsible for earning nafkah. ${ }^{74}$

The contextualist/progressive who disagree with the textualist/ conservative and semi-textualist/moderate notions about inheritance, argue that the double portion for men and the single portion for women in the Qur'anic text was simply a tool to create justice in society at that time; and, that the text was a transitional text, not an absolute text. ${ }^{75}$ Both men and women should share an equal portion of an inheritance; a woman or a man may even get a larger portion depending upon agreed need. ${ }^{76}$ A number of NGOs and liberals in Muslim countries have called for equal inheritance rights, claiming that different treatment on the basis of gender violates international human rights. However, a more contextualist/progressive position is the common position, even taken by some Muslim women, that what God has ordained for shares cannot be changed. ${ }^{77}$

It can be summarised, therefore, that in terms of inheritance textualists argue that men should have a double portion whereas women should have a single portion of inheritance because a man is the main breadwinner in the family. The semi-textualist/moderate position is that because men have a double portion in inheritance compared to women, other types of charity should be found for women. A family agreement can be reached after each heir is aware of his/her portion. The contextualist/progressive view asserts that both a woman and a man should inherit an equal portion according to whoever needs more, regardless of gender, because today many women have the same responsibilities as the main male breadwinner.

\section{Equal Value as $A$ Witness}

The religious texts that have been considered as a reference to discuss an equal value as a witness is Al-Baqara, 282 which states:

$\mathrm{O}$ you who believe! When you contract a debt for a fixed period, write it down. Let a scribe write it down in justice between you. Let not the scribe refuse to write as Allah has taught him, so let him write. Let him (the debtor) who incurs the liability dictate, and he must fear Allah, his Lord,

74 Abdullah, interview (22 May 2010).

75 Subhan, Menggagas Fiqh Pemberdayaan Perempuan, p. 261.

76 Mulia, Muslimah Reformis, pp. 261-2.

77 Islam, Land and Property Research Series. 
and diminish not anything of what he owes. But if the debtor is of poor understanding or weak, or is unable to dictate for himself, then let his guardian dictate in justice. And get two witnesses out of your own men. And if there are not two men (available), then a man and two women, such as you agree for witnesses, so that if one of them (two women) errs, the other can remind her... ${ }^{78}$

One Hadith narrated by Abu Said Al-Khudri in Shohih Bukhori (Book 6: Menstrual Periods, No. 301) also addresses the witness issue:

Abu Said Al-Khudri narrated: Once Allah's Apostle went out to the Musalla (to offer the prayer) o 'Id-al-Adha or Al-Fitr prayer. Then he passed by the women and said, "O women! Give alms, as I have seen that the majority of the dwellers of Hell-fire were you (women)." They asked, "Why is it so, O Allah's Apostle?" He replied, "You curse frequently and are ungrateful to your husbands. I have not seen anyone more deficient in intelligence and religion than you. A cautious sensible man could be led astray by some of you." The women asked, "O Allah's Apostle! What is deficient in our intelligence and religion?" He said, "Is not the evidence of two women equal to the witness of one man?" They replied in the affirmative. He said, "This is the deficiency in her intelligence. Isn't it true that a woman can neither pray nor fast during her menses?" The women replied in the affirmative. He said, "This is the deficiency in her religion". 79

During the in depth interview many respondents, who usually took the textualist/conservative or semi-textualist/moderate position claimed that they were neither familiar with nor had ever heard or read the Hadith saying that women have a half brain to men and a half of religion. Therefore, in this point researcher do not report the textualist/ conservative view from interview. The following textualist/conservative point is from literature review.

Textualist-conservatives hold that whatever stated in the Qur'an is law. Therefore, Muslims should follow the law in the Qur'an and Hadith, including on the matter of witnesses. Textualist-conservatives accept the Qur'anic verse, ayat 282 which states that men have a higher status than women because they have more intellectual capability, leadership ability,

78 Mohsin Khan (tran.), "Al-Baqara: 282”.

79 Sahih Bukhari, "6. Menstrual Periods: 301”, 6. Menstrual Periods from Sabih Al-Bukhari, https://www.searchtruth.com/book_display.php?book=6\&translator=1\& start $=0 \&$ number $=0$, accessed 2 Nov 2018. 
and rights than women. This verse is supported by An-Nisa, 34 (about leadership) and the Hadith, i.e., that women have half of the intellectual capacity and also half of the religious value of men. Based on these literal interpretations, some textualist scholars, for example al-Asfhani from Iran, conclude that the value of two female witnesses is the same as that of one male witness. ${ }^{80}$ Ali Ahmad Jurhani in Tafsir Al-Qur'an alKarim, (2:1), argues that the witness matter relates to the fact that men are considered more rational than women; conversely, women are more emotional than men. ${ }^{81}$

Members of the semi-textualist/moderate group according to Aziz, Ilyas, and Subhan, criticise these texts saying that in the course of history, many Muslim women have been recognised as having more intellectual capability than men. ${ }^{82}$ For example, Aziz notes that: 'Aisyah, the Prophet Muhammad's wife, is known as a woman narrator numerous Hadiths from the Prophet Muhammad. They also argue that the witness text was revealed as a response to a business issue, e.g., trade and debt of the time. Historically, not many women were good traders: most of them stayed at home doing domestic tasks; therefore, their experience in business matters did not equal that of men. Another reason is that in the Hadith the words "some of you" not "all of you", can be interpreted as meaning that not all women's intellectual capacity is less than men's. Therefore, semi-textualist-moderates conclude that just one female witness is acceptable if she is capable or is an expert on the issues under scrutiny.

A male contextualist/progressive respondent from an Islamic university, argued that the term 'a half brain' was insulting. He stated:

I think at that time (in the prophet Muhammad era) many women stayed at home only; therefore, they did not maximise their intellectual potential. As a result, their ability to be witnesses was only accounted a half to men.

${ }^{80}$ Hamim Ilyas, "Kodrat Perempuan: Kurang Akal dan Kurang Agama”, in Perempuan Tertindas? Kajian Hadis-Hadis "Misoginis", ed. by Mochamad Sodik and Inayah Rohmaniyah (Yogyakarta: eLSAQ Press \& PSW UIN Sunan Kalijaga, 2005), pp. 51-65.

81 Tim Lajnah Pentashihan Departemen Agama (ed.), Tafsir Al-Quran al Karim.

82 Erwati Aziz, "Akal dan Agama Perempuan: Kritik terhadap Hadis tentang Kekurangan Akal dan Agama Perempuan”, in Relasi Jender dalam Islam, ed. by Erwati Aziz (Kartasura: PSW STAIN Surakarta Press, 2002), pp. 85-106; Ilyas, "Kodrat Perempuan: Kurang Akal dan Kurang Agama”, pp. 51-65. 
I have read many books explaining that it does not mean that women have a half brain to men, it's just a matter of how to optimise the brain. Long time ago we did not have woman judges but now there are many women judges in Indonesia, it is important to read the Hadiths and link them to the spirit of the Qur'an. ${ }^{83}$

Another contextualist/progressive respondent from an Islamic university, Wira, argued that considering women's values as half of that of men to be witness is implicit in the interpretations of women's creation, Wira observed:

The belief that women were created from men's ribs led to the other gender issues such as women lack of brains, thus women cannot be witnesses, women cannot be guardians ... so for me the interpretation of women's creation should be explained properly ... In the Qur'an there is a story about the Queen of Bilqis who was known as laha ansyur adhim (meaning she possessed superpower). This title was not given to the prophet Sulaiman in the Qur'an but to a woman, the Queen of Bilqis. ${ }^{84}$

Contextualist/progressive scholars reject the witness Hadith and reinterpret the Qur'anic passages because the textualist/conservative interpretations are not in line with the universal values of the Qur'an. In addition, they are contradicted by the fact that throughout history many great women have achieved great reputations. ${ }^{85}$ According to Ilyas, an Indonesian contextualist/progressive Muslim man, many Indonesian women have become actively involved in public life; so, clearly attributing only half the value of men to female witnesses is not acceptable. ${ }^{86}$ The contextualist/progressives claim that the evidence supports the fact that both men and women can perform equally well intellectually; in Indonesian universities, for example, many of the best students are women. Asghar Ali Engineer argues that the witness texts are open to reinterpretation because they are only representative of women's

83 Abdullah, interview (22 May 2010).

84 Wira, interview (8 May 2010).

85 Aziz, "Akal dan Agama Perempuan: Kritik terhadap Hadis tentang Kekurangan Akal dan Agama Perempuan”.

86 Ilyas, "Kodrat Perempuan: Kurang Akal dan Kurang Agama". 
experience in business at that time. ${ }^{87}$

Summary of those discussions is that textualists assert that it is proper that one male witness is equal to two females in Islamic law because men are smarter than women. Semi-textualist/moderate people say that one female witness is acceptable if she is capable or an expert on the relevant issues. In history, many Muslim women were recognised as having more intellectual capability than men. Contextualist/progressive people argue that men and women are equally capable of being witnesses. In the Indonesian context, within which many women become actively involved in public life, the proportion that two female witnesses equal one male is not acceptable. The spirit of women's witness Hadith contradicts the basic values of the Quran.

\section{Symbolic Equality of Women in The Creation Story}

Gender differences that makes men to a higher status than women cannot be separated from Muslim beliefs regarding the creation of human beings. Like Judaism's Torah and Christianity's bible, ${ }^{88}$ Islam's canonical text, the Qur'an, also has a creation story in which raise a controversy. Texts about creation of the first human beings are found in the Qur'an as well as Hadiths related by Abu Hurairah in:

An-Nisa, 1: O mankind! Be circumspect in keeping your duty to your Sustainers who created you (plural) from one being (nafsin wahidah) and spread from her (minha), her mate a (zaujaha) and spread from these two human beings many men and women. ${ }^{89}$

As narrated by Abu Huraira, Allah's Apostle said: "The woman is like a rib; if you try to straighten her, she will break. So if you want to get benefit from her, do so while she still has some crookedness". ${ }^{90}$

87 Asghar Ali Engineer, The Rights of Women in Islam (London: C Hurst \& Co Publishers Ltd, 1992).

${ }^{88}$ Arthur Stanley Maxwell, The Bible Story, vol. 7 (Hagerstown, MD: Review and Herald, 1956).

89 Mohsin Khan (tran.), “An-Nisaa: 1”, 4. An-Nisaa, 176 verses, The Women, Medinan, https:/ / www.searchtruth.com/chapter_display.php?chapter=4\&translator=5\&show_ arabic $=1$, accessed 11 Feb 2017.

90 Sahih Al-Bukhari, “62. Wedlock, Marriage (Nikaah): 63-113”, SearchTruth.com, https:/ / www.searchtruth.com/book_display.php?book=62\&translator=1\&start=109, accessed 11 Nov 2018. 
As narrated by Abu Huraira, Allah's Apostle said: "Treat women nicely, for a woman is created from a rib, and the most curved portion of the rib is its upper portion, so, if you should try to straighten it, it will break, but if you leave it as it is, it will remain crooked. So treat women nicely". ${ }^{91}$

Textualist/conservative respondents argued in favour of the truth that men and women were created from different material. This is in line with textualist/conservative scholars saying that hadist are shabih (authentic) and that their meaning suggests that woman was created from a man's rib; as a result, woman is inferior to man. ${ }^{92}$

Zaki, a male respondent from a public university, supported the Hadith saying that woman was created from a rib as valid and true.

Although there are many interpretations about women creation, I believe that the Hadith [a woman was created from a rib] is valid. I do not ignore that Hadith. In the process, a woman was created from a rib and Adam was created from clay ${ }^{93}$

Scholars from the second group, whom I categorise as semitextualist-moderates, argue that these texts are also shahih; but, the interpretation is different from that of the first group. As they interpret these Hadiths as metaphors, meaning that a woman should be treated well. In regard to the second group, although they interpret the texts differently using metaphors, problematic implications. It means that because men and women are different, they should be treated differently. But, although they should be treated differently, this group nevertheless emphasises that although they are different, they have the same status and rights.

Employing a semi-textualist/moderate approach, some respondents (Laila and Ana) argued that the first woman was created from a man's ribs is only an analogy. Basically, men and women were created from the

91 Sahih Al-Bukhari, “62. Wedlock, Marriage (Nikaah): 55-548”, SearchTruth.com, https:/ / www.searchtruth.com/book_display.php?book=62\&translator=1\&start=109, accessed 11 Nov 2018.

92 Agus Muhammad Najib, "Penciptaan Perempuan dari Tulang Rusuk Lakilaki?", in Perempuan Tertindas? Kajian Hadis-Hadis "Misoginis", ed. by Mochamad Sodik and Inayah Rohmaniyah (Yogyakarta: eLSAQ Press \& PSW UIN Sunan Kalijaga, 2005), pp. 51-65.

93 Zaki, interview (27 May 2010). 


\section{same essence.}

Men and women should be created from the same material ... the term 'rib' is only a symbol that women are part of men. But in terms of creation, logically they were created from the same essence which was clay. In the current situation men and women are created from the same materials. ${ }^{94}$

The men's and women's creation is the same. The Hadith saying that a woman was created from man's rib is only an analogy. This means that rib closes to the hearth. Therefore, a woman should be loved and protected. Woman was not created from a skull because she should not be worshipped and not from a leg bone because women should not be trampled underfoot. ${ }^{95}$

Nisa and Zihan explain why contextualist/progressive respondents rejected the idea that men and women were created differently. Nisa argued that the notion of women being created from men's ribs was only a tool to dominate women.

Women are human beings and human beings are created from blood and the combination between sperm and egg. I do not agree with the idea that women were created from a rib. This idea is a weapon for people who do not like women, for me men and women were created from the same essence. ${ }^{96}$

Zihan, a male respondent from an Islamic university, argued that the idea of women's creation from men's ribs is inherent in the Christian tradition (the Old Testament). "For me, men and women were created from the same essence". ${ }^{97}$

Contextualist/progressive scholars argue that the statement in the Hadith that claiming woman was created from the rib of a man contradicts the Qur'anic statement in verses An-Nisa, 1 and Al A'raf, 189 that man and woman were created from the same kind of substance or from a single soul. In terms of understanding An-Nisa, 1, they analyse

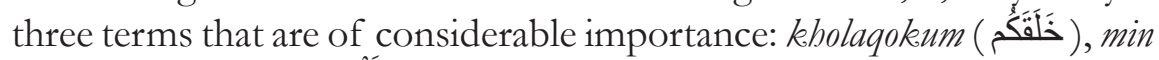

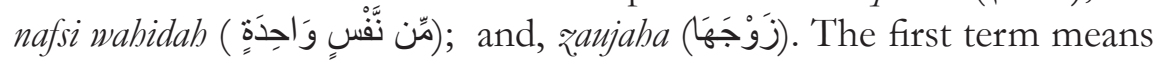

\footnotetext{
94 Laila, interview (3 Jun 2010).

95 Ana, interview (1 Jun 2010).

96 Nisa, interview (17 May 2010).

97 Zihan, interview (19 May 2010).
} 
'I create you', and applies to either man or woman. In Arabic, kum can be used for both man and woman. The second term, min nafsi wabidah, means a single soul or essence. According to Amina Wadud, conceptually this term is neither masculine nor feminine. ${ }^{98}$ She argues that these words were never used in the Qur'an with reference to any created self other than human kind and that God never intended to begin the creation of human kind with a male. Engineer, agrees with Wadud's interpretation of this term and emphasises that whatever its meaning, it indicates that man and woman are from the same kind. ${ }^{99}$ The last term, zaujaha, means 'mate', either male or female. The Qur'an makes no mention of Hawwa/ Eve being created from Adam's rib, for it implies inferiority. The Qur'an never suggests that Adam marked the beginning of the human race. Therefore, there is no discrimination against woman and her creation, according to this particular interpretation.

Thus, clearly in the Qur'an there is no difference between the creation of men and women. However, it is unclear in the Hadiths reported by Al Bukhari and Al Muslim, who state: "A woman is like a crooked rib or she was created from a rib: it will break if you try to straighten it". If one looks at these Hadiths closely, they say that 'a woman is created from a rib' or 'a woman is like a rib'. It does not state that woman was created from man's rib. The 'rib' in these texts does not belong to somebody specific: nor does it belong to man or Adam. Therefore, it is inappropriate for people to interpret them by adding the terms 'man's rib' or 'Adam's rib'. Furthermore, these Hadiths were drawn from traditional works; so there is no guarantee that they indicate original Islamic teachings. Some transmitters of women's creation Hadiths are considered to be single reporter and is thus unreliable. As a result, "these Hadiths are gharib and daif (weak and the lowest grade of Hadith classification)". ${ }^{100}$

Historically, Islam is the latest monotheistic religion, after Judaism

98 Alimatul Qibtiyah, Paradigma Pendidikan Seksualitas Perspektif Islam: Teori dan Praktik (Yogyakarta: Kurnia Kalam Semesta, 2006), pp. 39-40.

99 Engineer, The Rights of Women in Islam, p. 42.

100 Riffat Hassan, "The Issue of Woman-Man Equality in the Islamic Tradition", in Eve \& Adam: Jewish, Christian, and Muslim Readings on Genesis and Gender, ed. by Kristen E. Kvam, Linda S. Schearing, and Valarie H. Ziegler (Bloomington: Indiana University Press, 1999), p. 473. 
and Christianity. Christians are taught about popular story of Adam and Eve and their role in human creation (see Genesis 2:18-24). Therefore, the Hadiths account of the creation of women may have been influenced by the dominant beliefs of the time. ${ }^{101}$ In addition, the prevailing patriarchal culture may also have impacted upon the Hadiths. Generally speaking, the Hadiths may be understood as products of the culture of the time. But, culture changes over time; so, people cannot simply take for granted a culture from the past.

Based on the above exploration it can be concluded that textualists/ conservative argue that according to the texts, woman was created from man's rib. Whereas semi-textualist/moderate people say that woman was created from man's ribs is only an analogy. Contextualist/progressive people noted that men and women were created from the same essence. The spirit of creation of women in the Hadith contradicts the basic value in the Quran.

\section{Concluding Remarks}

Based on the above discussiion, I have documented the diversity of thoughts among Muslim intellectuals and gender activists on gender issues in the light of their faith. It becomes clear that 'textualistconservative' and 'contextualist/progressive' scholars show the most strongly contrasting views on gender issues in Islam. 'Semi-textualistmoderates' present their views flexibly: sometimes their views match those of the textualist-conservatives: sometimes they align closely with the contextualist/progressives. Based on their views and the argument they say, semi-textualist-moderates' and contextualist/progressives' views seem close to the stance adopted by many Western feminists.

101 Najib, "Penciptaan Perempuan dari Tulang Rusuk Laki-laki?”, pp. 51-65. 
Mapping of Muslims' Understandings on Gender Issues in Islam

\section{BIBLIOGRAPHY}

Abdullah, M. Amin, Studi Agama: Normativitas atau Historisitas?, Yogyakarta: Pustaka Pelajar, 1996.

Afsaruddin, Asma, Hermeneutics \& Honor - Negotiating Female "Public" Space in Islamic/Ate Societies, Cambridge: Harvard University Press, 2000.

Al-Bukhari, Sahih, “62. Wedlock, Marriage (Nikaah): 63-113”, SearchTruth. com, https: / / www.searchtruth.com/book_display.php?book=62\&t ranslator $=1 \&$ start $=109$, accessed 11 Nov 2018.

----, “62. Wedlock, Marriage (Nikaah): 55-548”, SearchTruth.com, https:/ / www.searchtruth.com/book_display.php?book $=62 \&$ translator $=1 \&$ start $=109$, accessed 11 Nov 2018.

Amal, Taufik Adnan and Samsu Rizal Panggabean, "A Contextual Approach to the Qur'an", in Approaches to the Qur'an in Contemporary Indonesia, ed. by Abdullah Saeed, London: Oxford University Press, 2005.

Aziz, Erwati, "Akal dan Agama Perempuan: Kritik terhadap Hadis tentang Kekurangan Akal dan Agama Perempuan”, in Relasi Jender dalam Islam, ed. by Erwati Aziz, Kartasura: PSW STAIN Surakarta Press, 2002.

Bacchi, Carol Lee, Same Difference: Feminism and Sexual Difference, Sydney: Allen \& Unwin, 1990.

Barton, Greg, "Neo-Modernism: A Vital Synthesis of Traditionalist and Modernist Islamic Thought in Indonesia”, Studia Islamika, vol. 2, no. 3, 1995 [http://dx.doi.org/10.15408/sdi.v2i3.827].

Bleicher, Josef, Contemporary Hermeneutics: Hermeneutics as Method, Philosophy and Critique, London; Boston: Routledge \& Kegan Paul, 1980.

Buletin Al-Ilmu, "Kedudukan Wanita dalam Islâm”, Akhwat.web.id, http://akhwat.web.id/muslimah-salafiyah/membantah-feminis / kedudukan-wanita-dalam-islam/, accessed 12 Apr 2018.

Burhanudin, Jajat and Oman Fathurahman (eds.), Tentang Perempuan Islam: Wacana dan Gerakan, Jakarta: Gramedia Pustaka Utama \& Pusat Pengkajian Islam dan Masyarakat, 2004.

Bustamam-Ahmad, Kamaruzzaman, "Contemporary Islamic Thought 
in Indonesian and Malay World: Islam Liberal, Islam Hadhari, and Islam Progresif", Journal of Indonesian Islam, vol. 5, no. 1, 2011, pp. 91-129-129 [http://dx.doi.org/10.15642/JIIS.2011.5.1.91-129].

Doorn-Harder, Pieternella van, Women Shaping Islam: Reading the Qur'an in Indonesia, Urbana: University of Illinois Press, 2006.

Engineer, Asghar Ali, The Rights of Women in Islam, London: C Hurst \& Co Publishers Ltd, 1992.

Faishal, Abdullah, “Konsep Qawwam di Dalam Al Qur'an”, in Relasi Jender dalam Islam, ed. by Erwati Aziz, Kartasura: PSW STAIN Surakarta Press, 2002.

Hassan, Riffat, "The Issue of Woman-Man Equality in the Islamic Tradition", in Eve \& Adam: Jewish, Christian, and Muslim Readings on Genesis and Gender, ed. by Kristen E. Kvam, Linda S. Schearing, and Valarie H. Ziegler, Bloomington: Indiana University Press, 1999.

Ilyas, Hamim, "Kodrat Perempuan: Kurang Akal dan Kurang Agama”, in Perempuan Tertindas? Kajian Hadis-Hadis "Misoginis", ed. by Mochamad Sodik and Inayah Rohmaniyah, Yogyakarta: eLSAQ Press \& PSW UIN Sunan Kalijaga, 2005.

Sait, M. Siraj and Hilary Lim, Islam, Land and Property Research Series, vol. 5: Muslim Women and Property, Nairobi: UN-HABITAT, 2005.

Kloos, David and Ward Berenschot, "Citizenship and Islam in Malaysia and Indonesia", in Citizenship and Democratization in Southeast Asia, ed. by Ward Berenschot, H.G.C. Schulte Nordholt, and Laurens Bakker, Leiden: Brill, 2016, pp. 178-207.

Maxwell, Arthur Stanley, The Bible Story, vol. 7, Hagerstown, MD: Review and Herald, 1956.

Miles, Matthew B., A. Michael Huberman, and Johnny Saldana (eds.), Qualitative Data Analysis, Los Angeles: Sage, 2014.

Mohsin Khan (tran.), "An-Nisaa: 34", 4. An-Nisaa, 176 verses, The Women, Medinan, https://www.searchtruth.com/chapter_display. php? chapter $=4 \&$ translator $=5 \&$ show_arabic $=1$, accessed $11 \mathrm{Feb}$ 2017.

---- (tran.), "Al-Ahzaab: 33", 33. Al-Ahqaab, 73 verses, The Clans, Medinan, https://www.searchtruth.com/chapter_display.php?chapter=33\&t 
ranslator=5\&show_arabic $=1$, accessed $11 \mathrm{Feb} 2017$.

--- (tran.), "Al-Baqara: 282", 2. Al-Baqara, 286 verses, The Cow, Medinan, https://www.searchtruth.com/chapter_display. php? chapter $=4 \&$ translator $=5 \&$ show_arabic $=1$, accessed $11 \mathrm{Feb}$ 2017.

--- (tran.), "An-Nisaa: 7-11", 4. An-Nisaa, 176 verses, The Women, Medinan, https://www.searchtruth.com/chapter_display. php? chapter $=4 \&$ translator $=5 \&$ show_arabic $=1$, accessed $11 \mathrm{Feb}$ 2017.

--- (tran.), “An-Nisaa: 1", 4. An-Nisaa, 176 verses, The Women, Medinan, https://www.searchtruth.com/chapter_display. php? chapter $=4 \&$ translator $=5 \&$ show_arabic $=1$, accessed 11 Feb 2017.

Mubarak, M. Zaki, Genealogi Islam Radikal di Indonesia: Gerakan, Pemikiran, dan Prospek Demokrasi, Jakarta: LP3ES, 2008.

Mulia, Siti Musda, Muslimah Reformis: Perempuan Pembaru Keagamaan, Bandung: Mizan, 2005.

Najib, Agus Muhammad, "Penciptaan Perempuan dari Tulang Rusuk Laki-laki?", in Perempuan Tertindas? Kajian Hadis-Hadis "Misoginis", ed. by Mochamad Sodik and Inayah Rohmaniyah, Yogyakarta: eLSAQ Press \& PSW UIN Sunan Kalijaga, 2005.

Naseef, Fatima Umar, Menggugat Sejarah Perempuan: Mewriudkan Idealisme Gender Sesuai Tuntunan Islam, trans. by Burhan Wirasubrata and Kundan D. Nuryakien, Jakarta: Cendikia Centra Muslim, 2001.

Nurmila, Nina, "The Influence of Global Muslim Feminism on Indonesian Muslim Feminist Discourse", Al-Jami'ab: Journal of Islamic Studies, vol. 49, no. 1, 2011, pp. 33-64 [http://dx.doi.org/10.14421/ ajis.2011.491.33-64].

Qibtiyah, Alimatul, Paradigma Pendidikan Seksualitas Perspektif Islam: Teori dan Praktik, Yogyakarta: Kurnia Kalam Semesta, 2006.

Rahman, Fazlur, Islam \& Modernity: Transformation of an Intellectual Tradition, Chicago: University of Chicago Press, 1982.

Romli, Mohamad Guntur, Muslim Feminis: Polemik Kemunduran dan Kebangkitan Islam, Jakarta: Freedom Institute, 2010. 
Saeed, Abdullah, "Introduction: the Qur'an, Interpretation and the Indonesian Context", in Approaches to the Qur'an in Contemporary Indonesia, ed. by Abdullah Saeed, London: Oxford University Press, 2005.

----, Interpreting the Qur'an: Towards a Contemporary Approach, London; New York: Taylor \& Francis, 2996.

Sahih Bukhari, "6. Menstrual Periods: 301", 6. Menstrual Periods from Sabih Al-Bukhari, https://www.searchtruth.com/book_display.php?bo ok $=6 \&$ translator $=1 \&$ start $=0 \&$ number $=0$, accessed 2 Nov 2018 .

Subhan, Zaitunah, Menggagas Fiqh Pemberdayaan Perempuan, Jakarta: elKahfi, 2008.

Suryakusuma, Julia I., Sex, Power, and Nation: An Anthology of Writings, 1979-2003, Jakarta: Metafor, 2004.

Tim Lajnah Pentashihan Departemen Agama (ed.), Tafsir Al-Quran al Karim, vol. 2, Kudus: Menara Kudus, 1996.

Wadud, Amina, Qur'an and Woman: Rereading the Sacred Text from a Woman's Perspective, 2nd ed., New York: Oxford University Press, 1999.

Woodward, Mark R., "Indonesia, Islam, and the Prospect for Democracy”, SAIS Review, vol. 21, no. 2, 2001, pp. 29-37 [http:// dx.doi.org/10.1353/sais.2001.0053]. 